$\begin{array}{cccc}\text { S sciendo } & \text { International Conference KNOWLEDGE-BASED ORGANIZATION } \\ \text { Vol. XXV } & \text { No } 1 & 2019\end{array}$

\title{
HYPERTEXT ORGANIZATION AS A MODEL OF ORGANIZATION IMPROVING THE FLOW OF KNOWLEDGE
}

\author{
Agnieszka SZCZYGIELSKA \\ War Studies University, Warsaw, Poland \\ a.szczygielska@akademia.mil.pl
}

\begin{abstract}
The article refers to a non-classic model of an organization, which is a hypertext organization. The hypertext organization combines a highly hierarchical organizational structure with the flexibility of management solutions supporting the conversion of various types of knowledge. It is considered to be a one of the most adequate models for managing the organization of the 21st century. Thereby, it contains in its assumptions solutions corresponding to challenges of the knowledge age and management of knowledge workers. The hypertext organization is able to successfully meet difficult requirements of the modern market and needs of an evolving society of different generations. It is important to show that the hypertext organization, being able to switch between "contexts" of knowledge creation, enables an efficient response to changing internal and external knowledge requirements.

The article is a theoretical discourse, the aim of which is to outline a concise characterization of a new solution in the subject of organizational structures, present the essence of hypertext solutions and show chances and capabilities of knowledge management in such organizations, that finally allow a transformation of institutions in intelligent organizations. Special attention will be paid to strongly hierarchical organizations such as uniformed services, especially the armed forces.
\end{abstract}

\section{Keywords: management, hypertext organization, armed forces}

\section{Introduction}

The concept of hypertext has been taken from the world of computers and the Internet. The term hypertext was introduced into the world of science by Ted Nelson in the early 1960s. In his understanding, hypertext means non-sequential writing. For the reader, hypertext offers several different branches to acquire the meaning of the written text. Hypertext does not really have either the beginning or the end, because it is the reader who decides for how long and which paths to follow in the hypertext labyrinth.

By transferring the above to business, classical organisations would correspond to a sequential text that is read "from beginning to end". Hypertext organisations are multi-context organisations with very many levels of meaning. Different words, actions or events can have an additional, deeper meaning, carry a hidden message or be associated with other elements and bring to mind something specific. These procedures are often intentional and used mainly in the transmission of information and its management, but also in other activities in the organisation, when their ambiguity is needed. Each user can subjectively shape, according to their own opinion, the reception of various signals resulting from organisational activity. In addition, in the era of networking, knowledge-based economy and the 
accessibility of various means of data transmission, information transmission and ways of absorbing knowledge, the ambiguity of reception, reading and interpretation increases.

The aim of the study is to outline the essence of hypertext solutions and to show the opportunities and possibilities of knowledge management in such organisations, which is ultimately supposed to transform the discussed institutions into intelligent organisations. Special attention will be paid to highly hierarchical public organisations, including the armed forces.

\section{Hypertext structure in response to new market conditions.}

A hypertext organisation communicating between the different levels of the knowledge creation structure enables itself to react efficiently to the changing requirements in the scope of internal and external knowledge. It operates in the real world, but also works virtually on the Internet. This organisation tries to combine the advantages of a classical structure (its order and clarity of power and roles) with a task-based structure, where any unnecessary structural ties are pushed to the background, temporarily suspended or limited to the necessary minimum. The premise is that formal ties should support workers in their chosen roles and should not pose an obstacle in their work. In a hypertext structure, the basis for construction is a specific type of bond in addition to those that are perceived as traditional (i.e. business, functional, technological or informational). In this case, for the benefit of smooth communication, contact paths which omit these formal lines of service are allowed. In a situation when work takes place in task forces, where specialists are appointed from different units, departments and branches, contacts with people who have nothing to do with a given project are unnecessary and only take time and hinder work and disturb the cleanliness of professional relations.
Such informal possibilities of cooperation and communication for the needs of the project facilitate the exchange of information, diffusion of necessary knowledge and creation of new knowledge necessary to perform subsequent duties and tasks. In relation to the above, the following distinguishing features of a hypertext organisation can be pointed out:

- amorphousness,

- holistic imagination,

- self-organisation of parts and the whole,

- different contexts of its perception and interpretation,

- global and elementary flexibility,

- repetitive gathering, processing and diffusion of managerial knowledge[1].

With the aforementioned multi-layered nature of the discussed hypertext organisation, it is possible to distinguish its key layers, such as:

- the business system layer, which includes daily routine activities and can be presented in the form of an organisational structure,

- design teams layer, including the task/project teams consisting of employees coming from different cells of the business system,

- a knowledge base layer in which the knowledge created by the two previous layers is categorised and contextualized [2].

In this type of organisation, the bureaucratic structure effectively implements, uses and accumulates new knowledge by recognising the value of content and combining sets of information. A process of internalisation and knowledge combination takes place here. Task forces are necessary to generate new knowledge through socialisation and externalisation. Here, the efficiency and stability of bureaucracy is combined with the effectiveness and dynamism of task forces, and this in turn is combined with a third layer, i.e. the knowledge base, which functions as a sort of a "clearing house" for 
the new knowledge generated in the business system layer and the design team layer[3].

With regard to the above characteristics, it should be stressed that for a hypertext organisation to function effectively, five requirements must be met in practice, i.e. intent, autonomy, fluctuation, creative chaos, excess and diversity. Intention is reflected in the development vision, while autonomy is needed to create the conditions for the possibility of randomly finding solutions. Fluctuation and creative chaos strengthen the sense of crisis and the need for change, causing so-called intellectual tension. Excess, in turn, concerns the conscious transformation of information concerning the activity, management responsibility or development visions of an organisation. Required diversity means "a minimum of diversity for organisational integration and a maximum of diversity for the effective amputability of the organisation to the environment"[4]. As can it be seen from the above considerations, the features of hypertext structure influence the shaping of certain features of its environment and vice versa. It is a constant, mutually supportive interaction.

\section{Hypertext organisation and knowledge management}

A hypertext organisation is a valuable concept and at the same time a tool, through its assumptions, in the process of creating knowledge. Traditional features of classical structures and bureaucratic solutions are eliminated here as they hinder development, progress and block the release of the potential inherent in employees. Some of the features standing out here are the strong centralisation, lack of delegation of powers, zero participation and wide control. It is not forgotten that strong top-down and centralised "...control is archaic and selflimiting. Diversity and innovation flourish when power and information are highly decentralized"'[5].
These solutions combine the advantages of several models of knowledge management, i.e. process, Hedlund model or resource model, thus creating synergistic opportunities for effective management and knowledge shaping, as well as building and strengthening smooth channels of information flow, taking care of the purity of content of this resource.

It seems that the awareness of the role that information plays today and the resulting knowledge is becoming more and more important. Unfortunately, attempts to implement concepts or even single tools supporting knowledge management are made much more often in commercial enterprises than in other types of institutions, especially public institutions. In relation to the global requirements and EU programmes needing more intensive development of an efficient knowledgebased economy in Poland and thus the creation of intelligent organisations and teaching organisations, such attempts have slowly started to be made in relation to the sphere of public organisations. However, these activities, and even more so the effects, are still barely visible.

It should be remembered that management solutions in the form of a hypertext organisation model are something different than IT solutions based on hypertext. Hypertext solutions in the form of computer systems have been functioning for a long time in our everyday life. These are e.g. Storyspace, MediaWiki, well-known Windows Help or popular Adobe Portable Document Format. Solutions from the above mentioned programs as well as the programs themselves are used on a daily basis in almost every organisation. Based on the models used here internal systems, dedicated to the specificity of specific organisations that meet their individual needs are created. In the U.S. Armed Forces, the first hypertext system network exists in the form of ARPANET, considered to be the direct ancestor of the Internet. It was created as an initiative of 
the U.S. Department of Defense (Pentagon) in the 1960s.

In the case of a hypertext organisation, an effective way of knowledge management can be observed, the two-directional one, both up and down the organisational structure with middle-up-down management. In such a solution, the key role is played by middle managers, as they have both information from the highest management and information from the lowest levels in the organisation, about their problems and needs. They also have constant contact with the lowest level, know their ideas and vision of change. Middle managers are like a knowledge buffer and capacitor between the two levels of the structure. They gather knowledge, codify and distribute it to the right units to get it to every place needed at the right time and in the right form and content. On the one hand, there is the classic top-down guidance according to the company's hierarchy lines and, at the same time, ideas are passed from the bottom of the structure to the top management. We can therefore speak of decentralisation and thus also of management flexibility and appreciation of grassroots initiatives.

In a situation of necessity and mobilisation, in the face of a challenge, the distance between the levels and the degree of formalisation is blurred. This is aimed at facilitating communication and facilitating the flow of knowledge and fluidity of interpersonal relations. Establishment of task or project teams in order to achieve the objectives and undertakings assessed highest for the development of institutions is made on the basis of prior identification of talents and key competencies of members of such teams. It is important that the people forming such groups are teams of experts working on a given issue. They can and often come from different organisational units and divisions, which additionally emphasizes the heterarchy of this management solution and shows the similarity of applied solutions in the task and matrix structure. In this organisation, there is a constant conversion of latent knowledge in the teams. A new quality of open knowledge is also created and a constant exchange of experience results in the creation of new ideas. These generated ideas and experiences are stored in knowledge bases, workflow systems, data warehouses and so on.

Additionally, the hypertext organisation constantly cooperates with the environment. It is vigilant and sensitive to social trends, economic changes and constantly monitors the market. There is a constant exchange of knowledge between the company and the environment. Here, solutions based on customer knowledge such as KCRM (knowledge customer relationship management), prosumerism or mass customisation are applied.

The hypertext organisation is capable of continuously and dynamically transforming the different knowledge contents generated by all its layers and somewhat switching smoothly between different approaches to this knowledge in different contexts depending on the situation.

\section{Hypertext structures in highly hierarchical organisations}

Recent years have gradually changed market laws in the field of products and services from standardisation to flexibility and individualisation of manufacturing or service provision. At the same time, a strong hierarchy is more and more often replaced by virtuality, and centralisation gives way to the openness of new structures of a heterarchical nature.

Unfortunately, in public organisations there is still too much hierarchical organisational structure. It can be assumed that in the case of some of them it is their specificity, but the lack of any changes in recent years also means that there have not even been any attempts made to loosen these tight bureaucratic nodes. This is even clearer in military organisations. However, it is almost certain that these organisations must 
create and engage efficient leaders and create such organisational structures that will be able to enter between the poles of the now desirable flat structure and the strongly hierarchised one [6]. This is all the more justified, especially in the face of networking, modern technologies, computerization, virtuality, modern weapons, simulation fighting or intelligent weaponry. In the face of new types of threats and increasingly complex ways of waging war, e.g. hybrid conflicts, changes are needed in the military in order to make management more efficient, make the structure more flexible and increase cooperation with the civil environment. In addition, it is becoming increasingly important to continuously build intellectual potential, conscious and systemic management of knowledge, implementation of the assumptions of an intelligent organisation and the use of new solutions, such as the above mentioned elements of hypertext organisation.

In modern models of organisations based on knowledge conversion, teamwork is very important because the latent knowledge is processed here. In addition, creativity and unconventional thinking are increasingly valued. The staff is required to constantly develop and improve their competences, abilities and applied solutions according to one of the principles of a learning organisation called personal mastery. The ability to function in constantly changing conditions, i.e. in the so-called homeokinesis, is an extremely valuable feature which proves openness, sharpness of employees, awareness of new management concepts and the willingness to self-improvement and self-organisation. It seems that, for example, the hypertext structure is a development of an intelligent knowledge management organisation and is able to cope with ever more dynamic markets and social changes.

The US Armed Forces have recognised the role of knowledge management in building an ever stronger and modern army ready to face the new challenges of tomorrow. As early as in 2005, Army Regulation 25-1, Army Knowledge Management and Information Technology recognised that knowledge management in the armed forces is a strategy for transforming itself into a network-centric, knowledge-based force and a further step towards the military of the future [7]. In other armed forces that create armies of the future, Australia has been managing intellectual potential for years. Internal documents state that for the military to become the military of the future, traditional methods will need to be strengthened and further developed through the use of knowledge-based solutions and by supporting management practices that are adapted to both commanders and soldiers [8].

As mentioned earlier, certain solutions in the form of hypertext systems in the field of IT, databases, knowledge warehouses, experience databases, case studies, behavioral analyses, etc. have been used by the armed forces for years. However, it is worth adding to ICT solutions and modern technologies a mental layer based on the work of human teams and organisational structures supported by the compact, multilevel repositories of knowledge mentioned above. Codification of knowledge and its subsequent use for staff training on the basis of real, past events should become everyday practice.

Scenarios should also be considered and developed on how bureaucratic solutions could be maintained, but in a dynamic and flexible way. The military peacekeeping organisation maintains a highly bureaucratic structure due to its specificity, but in times of war there are circumstances that force it to be more flexible and also to demonstrate the mobility of solutions, e.g. in the case of a hybrid conflict. Therefore, it is worth gradually making the structure more flexible, increasing the number of task forces, and putting more emphasis on training according to the talents of the staff. It is valuable for the development of this 
type of organisation to create one's own solutions adjusted to the specificity of the activity, and not only those modelled on the competition. Therefore, more emphasis should be put on converting one's own knowledge into useful solutions, e.g. in the field of technology, weaponry or computer systems.

In relation to the above, it seems that in the armed forces it is worth trying to implement permeable, modern solutions based on knowledge management, which will translate into a hybrid type of organisational structure.

\section{Conclusions}

In the era of striving to become a military of the future, fully network-centric and capable of fighting in cyberspace, i.e. meeting the requirements of the present day, conscious management of knowledge in the armed forces is becoming more often required. The idea of hypertext organisation is strongly connected with the assumptions of knowledge management concepts and models. These are in a way co-existing solutions, in which one side is dependent on the other.

Naturally, one should not negate the classic solutions that have been developed and proven so far, but more often combine them with new ones based on the principle of coexistence, e.g. classic structure with the possibility of oblique hypertext relations and the creation of task forces on an ad hoc basis. The ability to search for such innovative solutions should be correlated with the organisational intelligence possessed and developed by the armed forces, and such actions should result in strengthening the network-centricity of the armed forces, creating from them the army of the future announced in ministerial documents, and thus spawning an intelligent organisation efficiently managing the knowledge. As a result, the resilience to new types of threats should be increased, the defence potential should be strengthened and the level of national security should be increased.

\section{References}

[1] K. Perechuda, Organizacja hipertekstowa, Zeszyty Naukowe Wałbrzyskiej Wyższej Szkoły Zarządzaniai Przedsiębiorczości No. 1/2002, Refleksje społeczno gospodarcze, ed. M. Morawski, J. Tutaj, Wydawnictwo Wałbrzyskiej Wyższej Szkoły Zarządzania Przedsiębiorczości, Wałbrzych 2002, pp. 16

[2] I. Nonaka, H. Takeuchi, Kreowanie wiedzy w organizacji, Poltext, Warsaw 2000

[3] L. Prusak, Knowledge in Organisations, Elsevier Inc, USA 1997, pp. 108 - 109

[4] P.Kordel, Struktura hipertekstowa jako istotne narzędzie zarzadzania organizacja oparta na wiedzy, Organizacja i Zarzadzanie No. 1(5), Wydawnictwo Politechniki Śląskiej: Gliwice 2009, pp. 134

[5] W. Luciejewski, Organizacja XXI-go wieku, Solar Management System - organizacj afraktalna $w$ praktyce, webpage: https://luciejewski.files.wordpress.com/.../organizacjaxxi-wieku-1.pptx, downloaded: November 2015

[6] W. M. Hall, Stray Voltage: War in the Information Age, Naval Institute Press, Annapolis USA, 2003, pp. 16-17

[7] Army Regulation 25-1 Army Knowledge Management and Information Technology, Headquarters Department of the Army Washington, DC 15 July 2005

[8] Handbook of Research on Knowledge Management: Adaptation and Context, Örtenblad (ed.),Edward Elgar Publishing, 2014 p. 91 et seq 